\title{
The early Browning: Pastoral care in a pluralistic age and the method of practical moral inquiry
}

\author{
Author: \\ Mark Hestenes \\ Affiliation: \\ ${ }^{1}$ Department of Practical \\ Theology, University of South \\ Africa, South Africa \\ Note: \\ This article is published in the \\ section Practical Theology \\ of the Society for Practical \\ Theology in South Africa. \\ Correspondence to: \\ Mark Hestenes \\ Email: \\ hesteme@unisa.ac.za \\ Postal address: \\ PO Box 392, Pretoria 0003, \\ South Africa \\ Dates: \\ Received: 09 Jan. 2012 \\ Accepted: 14 Feb. 2012 \\ Published: 13 Aug. 2012 \\ How to cite this article: \\ Hestenes, M., 2012, 'The \\ early Browning: Pastoral care \\ in a pluralistic age and the \\ method of practical moral \\ inquiry', HTS Teologiese \\ Studies/Theological Studies \\ 68(2), Art. \#1211, 7 pages. \\ http://dx.doi.org/10.4102/ \\ hts.v68i2.1211
}

C 2012. The Authors. Licensee: AOSIS OpenJournals. This work is licensed under the Creative Commons Attribution License.
The past president of the International Academy of Practical Theology, Prof. Donald Browning, has written books and articles across a wide variety of topics concerning the correlation of many great fields of knowledge, including theology, psychology, philosophy, sociology, practical theology, ethics, family therapy and ecology over the past 40 years. Prof. Browning passed away on 03 June 2010. This left the author of this article with a desire to begin to reassess some of Browning's earlier reflections regarding his vision of pastoral care in a pluralistic age and the importance of his method of practical moral inquiry.

\section{Introduction}

Donald Browning was the Professor of Religion and Psychology and, most recently, the Professor of Religious Ethics and Social Sciences at the prestigious University of Chicago for more than 40 years. He also supervised 80 Masters and Doctoral graduates at the University of Chicago Divinity School during his tenure there. He included amongst his colleagues the internationally recognised theologians, David Tracy in Systematic Theology, James Gustafson in Ethics and Paul Ricoeur in Philosophy, and, prior to that, Paul Tillich in Systematic Theology, Seward Hiltner in Pastoral Psychology and Lawrence Kohlberg in the Psychology of Moral Development. Prof. Browning passed away on 03 June 2010, prompting the author of this article to reassess Browning's incredible diversity of writing and thinking through a series of articles, of which this is the third.

Browning's overall projects are exceedingly complex, ambitious and cosmopolitan. His books and articles touch on philosophy, sociology, social anthropology, theology, politics, psychology and ecology. Browning desires to influence university, church and world though his writings, as well as being concerned about the ecological future of the planet. The corpus of Browning's work now comprises over 20 volumes and a vast number of articles written over a 40-year period. Browning has visited South Africa on three occasions and shared his vision of a public practical theology and an ethically sensitive pastoral care, as well as a concern for a global just and equal regard' family to respond to the fragmentation of life in the age of pluralism, modernity and postmodernity.

It is the intention of this article to undertake a critical study of Browning's theory of pastoral care in a pluralistic age, with special reference to the usefulness of his revised correlation method and his method of practical moral reasoning through the presentation of a South African case study. Browning has made various claims about his method which are worthy of being tested. Firstly, Browning (1983a:15) argues that his method of practical moral reasoning can improve our care and counselling. This is particularly true of individual counselling, family counselling and even communal care. Secondly, Browning (1983a:122) claims that his method is primarily useful '... in order to straighten out our confusion when we get into a muddle'. According to Browning (1983a:120-121) this method has an infinite variety of potential uses. He advocates its use for experts, in various disciplines, who have gathered together to work out the norms for the church and society, through to congregations and ministers learning to use this method in deliberations together. He argues that his method can also be used for communal decision-making and even university public discourse on the issues facing society. It is a highly ecumenical method and can be used by church leaders, pastoral counsellors and secular psychotherapists as well. Thus, it is a truly elastic method (Hestenes 2009). Thirdly, Browning (1983a:122) argues that his method is actually implicit in most people's decision-making processes. Stephen Pattison (1998:44) notes that, 'It is pointed out that all that is really being suggested is a systematic step-by-step account of something that people do in a rather haphazard way.' Browning's major concern is to develop a critical reflective method for pastoral care and counselling through which theology and the social sciences can be mutually correlated and informing of one another. This critical method of pastoral reflection will be the final focus of this article. The author has limited this article to the Browning's early works and, as such, his detailed development of the broader field of Practical Theology after 1983 is not covered here. 


\section{Pastoral care in a pluralistic age}

Browning's (1983a) early writings can be described as being a response to modernity. He writes:

The most pervasive social fact of contemporary life at least for Western people is the relentless march of the forces of modernity ... Modernity seems to be the social impact of industrialization, technology, structural differentiation of basic social institutions, occupational specialization and urbanization. (p. 11)

Browning stresses in his writings that modernity is an ambiguous phenomenon. The positive results of economic and technological advancement need to be weighed against the negative forces of possible ecological extinction of the human race and the incredible confused choices that face humankind in the modern era. Life is characterised by uncertainty, pluralistic values, rapid social change and moral perplexity. Browning believes that pluralism can lead to fragmentation and disunity of shared life for both church and society.

In The moral context of pastoral care, Browning (1976:16) follows Max Weber by asserting that in times of social ambiguity, caregivers such as priests, doctors and psychotherapists take on a role of greater authority for organised religion and society. Care-givers become spiritual and moral guides who not only affect those visiting them with some need, but influence the wider society through their cultural vision. Care-givers thus have an impact far in excess of their meagre actions. Caregivers also give guidance and direction to communities.

Browning argues that the Judeo-Christian tradition is, above all else, rational, ethical and ascetic (a disciplined life-style with a willingness to suffer) and that all acts of care have a moral context. He stresses how important the religious and moral tradition is for acts of care and the vital need for the actions of care to be seen within the church context. The church community must become a community of moral discourse. Hence, pastoral care and counselling must confront modernity and be grounded in a community of moral discourse in order to offer a distinctive Christian moral care.

\section{The correlation method}

Tillich's method of correlation gives theological thinkers a means of comparing theology and psychological concepts. Tillich (1951:29-33) gives an extended discussion of his method in Systematic theology, in which he argues that the correlating of theology and psychology must go through three specific steps. The author summarises these steps in order, as follows:

- Structural wholes: Theology and psychology are autonomous bodies of knowledge circumscribed by definite limitations and intentions. Each has its own history, language system and community of meaning. The method of correlation begins with two separate systems in order to explicate the means of concepts in their contextual configurations. In the first step of correlation, no attempt is made to cross over boundaries between two disciplines.
- Correspondence: Both theology and psychology have points of correspondence between concepts. This does not mean that they are identical or have the same meaning; rather, concepts have some elements in parallel or which are analogous to one another. At some points there is a correspondence between the concepts of psychology and theology. One of the basic concerns of both theology and psychology is their experiences and view of humankind. Each discipline conceptualises humankind in terms consonant with its own system. Many theological conceptions seem to have psychological correlatives, for example salvation and wholeness, reconciliation and healing, being in Christ and maturity.

- Interdependence: Concepts can become interdependent. The concepts of theology and psychology will occasionally converge and become interdependent. They will be in tension and will thus be in a dialectical relationship with one another and will actually be defined by one another. Tillich (1951:33) writes, 'The divine human relationship is a correlation also in its cognitive side. Symbolically speaking, God answers man's questions and under the impact of God's answers man asks them. Theology formulates the questions implied in human existence and theology formulates the answers implied in divine self-manifestation under the guidance of the questions implied in human existence.'

According to Tillich then, theology gives answers to the questions raised by psychology. Hence he correlates questions from an analysis of existence with answers from the Christian revelation. Prof. Wayne Meeks (1983:129) describes this as a lateral approach to correlation, based on a dialogical or dialectical method.

\section{Browning's revised correlation method}

As one of the contributors within Browning's (1983b) Practical theology, Tracy (1983:78-80) modified Tillich's method by calling for a mutual critical correlation, in which the correlation of questions and answers is two-sided: theology and the social sciences conversing as equals. Thus, Christian tradition and praxis and other forms of social sciences and praxis are brought together in mutually constructive critical dialogue. The revised correlation approach also involves a serious conversation of Christian tradition, ethics, human reasoning, experience, scripture and the social sciences. The inclusion of experience (a characteristic of American empirical theology) and the social sciences as full partners in the dialogue or conversation is very significant. This leads to the following definition regarding pastoral theology:

Pastoral theology should rediscover itself as a dimension of theological or religious ethics. It is the primary task of pastoral theology to bring together theological ethics and the social sciences to articulate a normative vision of the human life cycle. Pastoral theology involves stating the appropriate relation between a moral theology of the human life cycle and psychodynamic, developmental, and other social science perspectives that describe or explain how human development comes about. (Browning 1983a:187) 
In Browning's (1966) doctoral thesis Atonement and psychotherapy, we see Browning correlating various theories of the atonement with psychotherapy and using psychological analogies for the purpose of theological construction. In this bold way, Browning is apparently saying that psychotherapy is, to a large extent, the earthly model for the nature of God's healing activity. Psychotherapy is analogous to God and his healing work. By studying psychotherapeutic healing processes, we can increase our understanding of how God works to heal and save us. Such study also increases our understanding of the fundamental nature of God. To explain this further, Browning (1966) appeals to the theology of the American empirical tradition to clarify the relationship between theology and psychology, remarking that:

The American empirical tradition of theology is less inclined to absolutize either the scientism of psychotherapy or the supernaturalism of theology; it bracketed these ultimate metaphysical commitments long enough to search out the fundamental analogies and formal similarities between the two approaches to human brokenness and cure. (p. 10)

The concept of correlation is valuable because it indicates provisionality about the end results of the process. The revised correlational approach is also open to the possibility that there might be a variety of relations between Christian praxis and contemporary praxis.

\section{The method of practical moral inquiry}

In this section we will look more thoroughly at Browning's revised correlation method as developed through his five interpenetrating levels of practical moral reasoning, which are intended to give moral guidance to both the means and goals of care.

In Religious ethics and pastoral care, Browning (1983a) introduces us to his well known method of practical moral inquiry as his distinguishing input to the revised correlation method. As mentioned previously (Hestenes 2009), Browning's method is elastic and harmonious and used in a variety of contexts. It remains a highly ecumenical method. Browning (1983a:46) stresses that the minister engaged in pastoral care must learn to be an ethical thinker and understand the methods of ethical thinking. The minister must be able to distinguish between deontological ethics of principle and teleological ethics of consequence, as well as the place of dispositional ethics or character ethics in a given context. The minister's ethical task is to assess where individuals are and ought to be and to develop the skills to move them toward the ethical ideal reality.

In this work, Browning (1983a) also introduces us to a more nuanced way of dealing with problems that face us. He calls for engaging in a 'hermeneutical rationality'. Hermeneutics is a process of interpretation aimed at bringing to understanding and making familiar the unfamiliar and making the incomprehensible understandable (Browning 1983a:49). He stresses that his theory of practical moral inquiry needs to be seen within a 'hermeneutical rational' model of conversation. Browning pictures a church as founded in praxis, whose activities are interrupted by problems that face the community to reflect on their current praxis. This reflection on praxis and theory requires method, which is the crux of this book.

Browning (1983a:100) has devised a flexible and interactive model for drawing together practical moral thinking. He introduces us to his method of four steps of practical action, as related to his five levels of practical reason. Firstly, the problem encountered must be immediately experienced and defined. Secondly, an attempt is made to get a clearer and deeper understanding of the problem. Thirdly, a creative step of critical reflection is undertaken by using the five levels of practical moral reasoning as a guide (see Table 1). Fourthly, a decisive strategy and step of decision-making is then undertaken.

Browning's (1983a:105) five levels of practical moral reasoning (Table 1) attempt to guide the individual and community toward the development of a practical moral theory aimed at improving praxis. The five levels direct interdisciplinary reflection and praxis and are described briefly as follows. The metaphorical and visional level attempts to tell people about the ultimate context of actions, the moral level indicates what people are obligated to do, the tendency-need level tells people which human needs they are justified in satisfying, the contextual-predictive (ecological) level focuses on the immediate context of people's actions and the rule-role level tells people how they are justified in meeting their ends and looks at their behaviour in terms of their position in the social structure. These levels are hierarchically related and the top-down approach may also suggest a movement from systematic theology, through ethics and psychology to practical theology. The method works both hierarchically top-down and laterally from objective to subjective pole for Browning (see Table 1). He shows a preference for beginning with the objective side of his methodological model (a model which illustrates a method) and, after setting norms, moves to the subjective or diagnostic parts of the model. He is thus concerned first with norming, then forming and then transforming.

\section{A case study: Pre-marital sex, Christian youth and a call to ministry}

Browning (1983a:19-24) has offered numerous cases, highlighting how he would use his method of rational moral

TABLE 1: Browning's model of practical moral reasoning.

\begin{tabular}{ll}
\hline Objective perspective & Subjective perspective (character) \\
\hline 1. Metaphorical and visional & 1.Faith development \\
2.Obligational & 2.Moral development \\
3.Tendency-need & 3.Motivational and emotional development \\
4.Contextual-predictive & 4.Ego development \\
5. Rule-role & 5.Rule-role development \\
\hline
\end{tabular}

Source: Browning, D., 1983a, Religious ethics and pastoral care, p. 102, Fortress, Philadelphia, PA 
reasoning to deal more adequately with problems that confront us. The author's use of Browning's method in this article will not be exhaustive but suggestive of how it may be used to improve our care.

The case study selected for this article was brought to the author's attention through his former doctoral student, Dr I. Simms. The reader should note that it is fictitious, being constructed by Dr Simms to demonstrate how the use of Browning's five level method helps to clarify counselling problems. With Dr Simms' permission, the author developed the study further for the purposes of this article, making it more complex and including personal insights with regard to how he would have dealt with the case should it have been a real occurrence. As such, it can be read as an exemplifier of particular - and challenging - pastoral counselling moments that occur when one is engaged in active ministry.

The case study in question involves a 23-year-old theological student (John) training for the ministry in a Protestant denomination The student attends a South African university where theological students live in a theological house, attend classes and partake in the social life of the university. The university is regarded as 'liberal' English-speaking and accepts a great deal of pluralistic student behaviour, with a strong emphasis upon 'individuality' often over community. The theological house, though liberal, is less liberal than the more secular institution to which it adheres. John comes from a broken home. At a recent chapel service where he led the service, his choice of hymns included 'I know that my Redeemer lives', which was echoed through his sermon topic 'Incredible Grace'. John is, however, in need of guidance on certain matters and so seeks out the counsel of the author.

Describing himself as a liberal pastoral care-giver, the author tends to err on the side of forgiveness, perhaps, in the past, over-identifying with liberal individualism over and against institutional church norms. The author therefore would surmise that the student approached him because he thought that the author would be less judgemental than his peers and more open to pre-marital sexuality amongst the youth. In counselling terms, John was looking for a match of value systems. What follows, then, is an attempt to relate Browning's method of practical moral reasoning to this case, with an aim towards practical action. The first two steps of Browning's method include defining the problem and listening deeply for understanding.

\section{Experiencing and defining the problem}

American empirical theology is based on the assumption that experience provides a major source for religious or secular reflection. There is a thickness about lived experience which is more than an attempt to describe and define it. Lived experience has to be seen within a context of 'relationships, where relationships are deemed experienceable' (Poling \& Miller 1985:70). God is a part of lived experience whilst being both transcendent and immanent. John's experience leads him to interaction with his past and present experience and to interact with the author and his experience as a person and counsellor. The process of reflection should thus result in theological and secular clarification and intentional actions. John had initially sought guidance because he said that he was having difficulty in being motivated in his studies. As he spoke, he mentioned in a matter of fact manner that he was sleeping with his girlfriend both in the college and elsewhere. He wondered if he was in danger of being removed from the institution and not becoming a minister of religion?

\section{Attention, listening and understanding}

In attending, listening and attempting to understand John's lived experience, it became apparent that his problem was not simply a lack of study motivation. His problem centred on the much larger question of pre-marital sexual relations between young people of a religious persuasion and his professional future. The romantic and emotional experience with his religious girlfriend resulted in a fear of future consequences. However, he was not concerned by pregnancy or HIV but exposure to the theological college and the likelihood of him being removed from the institution and not becoming a minister of religion, which was his ultimate goal.

\section{The five levels of practical moral reasoning The metaphorical level}

Critical moral reflection begins at the metaphorical level. Each person utilises one or more powerful ideas to describe the ultimate or religious context of existence. Browning (1983a:58) feels that H. Richard Niebuhr's three great metaphors of God the Creator (highlighting the particular relational goodness of life), God the Governor (expressing order and boundaries, transgression beyond results in sin) and God the Redeemer (stressing forgiveness and possibilities of renewal and change) help us orientate ourselves toward this ultimate context of human experience.

In terms of these metaphors, John's religious experience, chapel service and hymn choice stress God's love and grace unconditionally and focus on Christ the Redeemer. In their counselling sessions, he did not appear to feel that he was sinning and hence had no need for forgiveness and the possibilities of renewal and change, which indicates his partial understanding of redemption. He showed little interest in acknowledging God as Governor, which expresses order and boundaries, transgression beyond which results in sin. The third metaphor of God the Creator holds possibilities for a discussion of why God created us as sexual beings and the holiness of sexuality stressed by the Church, as defined by the general position of most churches in limiting sexual intercourse to marriage.

The objective side of the analysis is complemented by a subjective, characterological side. Browning argues for the use of Fowler's (1987:57-77) seven stages of faith development model to assess John's current level of faith development. John appears to be operating at both stage three, mythic-literal faith, and stage four, syntheticconventional faith. Faith in stage three stresses how children 
begin to question their images of faith. The interpretation of their beliefs tends to be literal, one-dimensional and selfcentred. John's partial appeal to Jesus as Redeemer allows him to select only what suits him and forget the fullness of faith as portrayed by other metaphors. Faith development in stage four indicates a person who develops an awareness of superiority or inferiority of the self in relation to others. There is an attempt to unify aspects of the self regarding attitudes, beliefs and values (faith) that will support his or her identity. The two stages cover roughly the chronological ages of seven to sixteen. John's ego-centric faith therefore is immature in focusing mostly on himself, his limited view of faith or grace which does not acknowledge the importance of sin and the need for forgiveness. His identity as a Christian person is ego-centric and not well developed.

\section{The obligational level}

Browning feels that this level has been neglected in the past and asserts that we need to have an objective set of moral principles in order to adjudicate concerning serious moral issues. Browning argues that the central ethical principle of Christianity is impartiality and equal regard. Browning finds this deontological ethic of impartial justice and equal regard highlighted through the Second Commandment. We need to give to others the equivalent consideration of our own interests. Browning also affirms the similar philosophical ideal of Rawls' (1971) Kantian ethic of equal regard and deontological reversible decision-making and impartial justice as worth emulating.

On the subjective side, Browning suggests using Kohlberg's (1981:10-18) six moral stages model to assess John's level of moral development. In following Kohlberg, one could estimate that John is exercising moral reasoning consistent with stage two, which is the morality of simple exchange. This stage stresses individualism and a morality which argues that the needs of others are considered only when they have something to offer in return. A person functioning in this way would follow principles when it is in their direct interests to do so. Basically, John's morality is egocentric with inadequate awareness of the repercussions of his actions upon his girlfriend or those in his immediate vicinity. Kohlberg's procedure would argue that if we could elevate the level of John's moral reasoning, this could help. Furthermore, as a counsellor one should not aim one's counselling more than one level above the one on which the counselee is currently positioned. Stage three reasoning indicates a morality of mutual interaction and role taking. In stage three, the individual develops an understanding of other people's feelings and shows a desire to sustain lasting relationships. Thus, one would attempt to broaden his comprehension of the wider expectations of his experience and actions which are relevant because of his connectedness to family, fellow students and community.

\section{The tendency-need level}

Browning (1983a:107) argues that having established the principle of impartiality and justice as fairness first, one can then turn to the question of diverging needs. This is the level where most pastoral counsellors begin their input, asking the question: What motivates people to adopt a certain attitude or behaviour? An attempt must also be made to determine which of all our needs are legitimate or fair or not. Psychodynamic neo-Freudian therapy is recommended here to enable the moral counsellor and counselee to understand the powerful motivations and emotions and needs which shape their behaviour.

One could begin by investigating why John's needs compel him to take the actions that he has chosen. Knowing that John comes from a disjointed family would lead one to surmise that he is seeking a closeness that he has failed to have for most of his life. He is also at an age of late sexual adolescence, which is a period of experimentation and sexual uncertainty and which is also a part of the growing identity of becoming a mature person (Browning 1983a:81). It would be important that he and his girlfriend talk to each other and to the counsellor about their understanding of premarital sexual intimacy. Their strong motivation for sexual intimacy is understandable at their age, but they need to realise that pre-marital sexual relations amongst Christian youth is still the exception and not the norm in South Africa. Two South African psychologists, Nicholas and Durrheim (1995:1328-1330), have made a scientific study of the relationship between religion and sexuality amongst firstyear university students. They write:

The study investigated the association of religiosity with sexuality, aids knowledge, attitudes and practices of 1,817 first year students in South Africa ... The results indicate that stated religious commitment is associated with a low propensity to engage in sexual intercourse and later onset of sexual activity. (p. 1329)

\section{The contextual-predictive level}

The contextual-predictive (ecological) level focuses on the immediate context of people's actions. There is a need to move beyond the individual and couple's immediate concerns to a concern about the wider social and cultural influences upon them. There are several key forces which shape John's experience and immediate context. Firstly, John's disjointed family stresses hesitation about relationships and marriage. Secondly, John's membership of the Christian house suggests that he abide by certain moral rules and norms which have limits. Thirdly, John's exposure to the liberal university atmosphere leads toward uncertainty over moral limits. Fourthly, the new South African culture is pluralistic and stresses openness to a great diversity of culture, relationships and types of marriage. For example, the State President of South Africa is a polygamist who also claims membership in a Pentecostal-Charismatic indigenous church. To try to appraise the power and influence of all of these cultural influences over the decisions of his life is complex indeed. At present, it would appear that a combination of the broken family background, age group experimentation and liberal university culture are playing a big role in his behaviour. 


\section{The rule-role level}

Role and rule theory are companions to reference group theory in sociology (Browning 1983a:71). This level tells people how they are justified in meeting their ends and looks at their behaviour in terms of their position in the social structure. John is simultaneously a son of a broken family, a person in a sexual relationship and a Christian person preparing for ministry. All of these postions have set implicit and explicit rules to which he has to adhere. In a broken family, it is not uncommon for the eldest son to take over the father's role. In his current situation in a theological house, religious and moral rules which are less flexible than those of the secular university should guide his behaviour. As a potential minister, it is apparent that a certain standard of moralsexual behaviour would be assumed. Would he be tempted towards adultery as much new literature about the ministry have noted of many ministers? Professor Donald Capps (1993:350-361) writes that when sex occurs in the parish between pastor and parishioner, something very dangerous is going on that gives intense moral and religious offence. He argues that this activity is one of the major dangers of misuse of pastoral power. He asserts that if a pastor is found to be guilty of an illicit sexual relationship with a parishioner, this will result in the pastor being advised to leave the ministry and take up another profession. He cites studies that show that $20 \%$ of clergy questioned acknowledged having experienced sexual activity outside their marriages. Can John transform his roles and rules in various contexts and be motivated sufficiently to make a fresh start toward a more mature view of the roles and rules under which he should now live?

\section{Strategy and decision-making}

The above analysis of where John is at present in his life has also highlighted a multiplicity of factors for exploration, which would enable John to know where he might wish to go from here. Browning (1983a:115) states that although the analysis may lead toward focusing on one level of his model, usually we will have to address all of these levels. Also, the process should not be mechanical but flow easily from level to level.

Firstly, John and his girlfriend should be given time to rethink their relationship from a Christian point of view. The gospel suggests that we think of loving relationships as being holy in God's sight. Sexuality is holy and therefore lived within God's sight. Their behaviour is not normative and they should try to get a clearer picture of their Christian understanding of sexual relationships with particular reference to pre-marital sex. The metaphors of God the Creator, Governor and Redeemer should be presented to enable a broad Christian discussion to take place. Do they feel that their behaviour is sinful or a stage toward possible personal commitment toward marriage? If they feel it is sinful, then there is the gospel of the second chance to which they could turn and experience a growth in intimacy and love beyond pre-marital sexual relationships.
Secondly, as his counsellor, the author would attempt to encourage John to take a broader view of his problem than merely focusing on his egotistical self, recommending that John and his girlfriend be included together in counselling. The author would indicate to them that their relationship is not really only personal but has broader ramifications for their families, the religious house in which John resides and his future profession. Indeed, for there to be a future, this should be taken as an opportunity to put things morally right and in perspective. In essence, the above points are in accord with Kohlberg's (1981) method of trying to encourage them to think more relationally and systems wise, rather than purely as isolated individuals. In this way they could raise their level of moral reasoning to a higher level and begin to sense the possibility to reason reciprocally and reversibly.

Thirdly, the institution would need to be informed if they continue to break the rules. His present role as a theological student has certain rules attached, which include the expectation that he lives a certain kind of moral life in regard to sexuality and wider human relations. John desires to become a minister, which has certain specific moral and ethical expectations placed upon him by the community which he may someday lead. How would he teach the youth and those involved in pre-marital sessions concerning matters of healthy Christian relationships and sexuality, if he does not know where he stands on key issues such as this? Ultimately, John and his girlfriend have to relate to institutions such as the theological house and church, which have specific moral expectations of their choices and behaviour.

\section{Critique and conclusion}

In all his writings, Browning argues that there is a danger that pastoral care and counselling may become absorbed in a normless, morally neutral psychotherapeutic mindset. He states (1983a:18) that without consistent ethical guidelines for thought and action, that pastoral care and counselling may become destructive for the individual and community. He calls for pastoral counselling to return to its heritage of rational moral guidance toward Christian moral living which exceeds the relatively narrow task of adjusting people's internal dynamics.

A major challenge for this moral counselling and moral caregiving is Browning's tendency to harmonise the levels, which suggests their easy-going compatibility when a counsellor and parishioner moves from level to level. Browning's (1976:105) strong support of neo-Freudian psychoanalysis at the third level is retrospective and assesses past actions, whilst the moral level is prospective and aims to change future behaviour. Also, Browning (1983a:110) acknowledges a conflict when he states that the moral issues may need to be bracketed if dealing with psychotherapeutic interventions at a crucial time in counselling. Hence, one first works with psychotherapy and then attempts to move people to the moral high ground sought by the counsellor and hopefully the parishioner. 
Browning's ethical focus has received both support and criticism. Gustafson (1970), Noyce (1989) and Tracy (1983) have given unqualified support. However, many pastoral and practical theologians have been critical of the view that pastoral and practical theology should be conceived of as a discipline under Christian ethics. Pattison (1988:39) is a good representative of this group - which also includes Capps (1983), Fowler (1987) and Poling and Miller (1985) - when he stresses that Browning is being reductionistic in arguing that pastoral care and counselling are little more than ethical discourse and training in morals and values. The church is also not just a seminar group of moral philosophers and the Christian religion is more than ethics and morality. Some aspects of pastoral care and counselling, such as healing, sustaining, guiding, reconciling and nurturing, do not give primacy to moral discourse at all times.

In the case of John, it is clear that the method helps one to broaden and deepen one's care and counselling by making a systematic reflective diagnosis before enabling a move toward action. In this author's opinion, Browning's reflective method helps one to understand better where John is in his life and gives one guidance toward where he ought to be. Working through the levels systematically, allows for a very rational and holistic approach to personal and interpersonal experience, problems and challenges. The reflective method illustrates that his method can improve our care and counselling and that it is particularly useful when we get into a muddle.

\section{Acknowledgements}

The author acknowledges the work of his former doctoral student, Dr I. Simms, whom, as mentioned earlier, shared with the author a shortened version of the case study on which this article is based.

\section{Competing interests}

The author declares that he has no financial or personal relationship(s) which may have inappropriately influenced him in writing this article.

\section{References}

Browning, D., 1966, Atonement and psychotherapy, Westminister, Philadelphia, PA. Browning, D., 1976, The moral context of pastoral care, Westminister, Philadelphia, PA.

Browning, D., 1983a, Religious ethics and pastoral care, Fortress, Philadelphia, PA. Browning, D. (ed.), 1983b, Practical theology, Harper and Row, San Francisco, CA. Capps, D., 1983, Life cycle theory and pastoral care, Westminister, Philadelphia, PA. Capps, D., 1993, 'Sex in the parish', Journal of pastoral care 47(4), 350-361. Fowler, J., 1987, Faith development and pastoral care, Fortress, Philadelphia, PA. Gustafson, J., 1970, The church as moral decision maker, Pilgrim, New York, NY. Hestenes, M., 2009, 'The early Browning: The strenuous mood', Practical Theology in South Africa 24(2), 122-139.

Kohlberg, L., 1981, The philosophy of moral development, vol. 1, Harper and Row, New York, NY

Meeks, W.A., 1983, The first urban Christians, Yale University Press, New Haven, CT.

Nicholas, L. \& Durrheim, K., 1995, 'Religiosity, aids and sexuality knowledge, attitudes, beliefs and practices of black South African first year university students', Psychological Reports 77, 1328-1330.

Noyce, G., 1989, The minister as moral counsellor, Abingdon, Nashville, TN.

Pattison, S., 1988, A critique of pastoral care, SCM press, London.

Poling, J. \& Miller, D., 1985, Foundations for a practical theology of ministry, Abingdon, Nashville, TN.

Rawls, J., 1971, A theory of justice, Harvard University Press, Cambridge.

Tillich, P., 1951, Systematic theology, vol. 1, University of Chicago Press, Chicago, IL.

Tracy, D., 1983, 'The foundations of practical theology', in D. Browning (ed.), Practical theology, pp. 61-82, Harper and Row, San Francisco, CA 